\title{
Neonatal Society*
}

\section{Meeting on Thursday, 2 July 1970 at Newcastle upon Tyne.}

\section{Communications}

F. Broughton Pipkin, Joan C. Mott, and N. R. C. Roberton (Nuffield Institute, Oxford). 'Pressor action on and inactivation by the circulation of Hypertensin (Ciba) in immature and adult rabbits.'

J. Dobbing and Jean Sands (Dept. of Child Health, University of Manchester). 'The human brain growth spurt.'

J. M. Parkin (Dept. of Anatomy, University of Newcastle upon Tyne). 'A comparison of the neurological development of European and Ugandan babies during the newborn period.'

M. J. Hardman (Institute of Child Health, London). 'The metabolism of brown adipose tissue after birth.'

I. C. S. Normand, E. O. R. Reynolds, and L. B. Strang (University College Hospital, London). 'Alveolar permeability to macromolecules in the fetal and newly ventilated lamb lung.'

C. Merlet, J. Hoerter, Claudette Devilleneuve and Catherine Tchobroutsky (Hôpital Broussais, Paris). 'Respiratory movements in fetal lambs in utero during the last month of gestation.'

G. S. Dawes, H. E. Fox, B. N. Leduc, G. C. Liggins, and R. T. Richards (Nuffield Institute, Oxford). 'Breathing and sleep before birth.'

K. W. Cross and Sheila R. Lewis (London Hospital Medical College, London). 'Cot death-an hypothesis.'

*Correspondence to Honorary Sscretary, Dr. D. P. Alexander, St. Mary's Hospital Medical School, Paddington, London W.2.
Omkar Bhakoo and J. W. Scopes (Hammersmith Hospital, London). 'Resting rates of oxygen consumption and extracellular fluid space in newborn babies.'

J. E. Bell, R. W. Graham, and R. J. Scothorne (Dept. of Anatomy, University of Newcastle upon Tyne). 'Prenatal parathyroid function.'

G. A. Neligan, (Princess Mary Maternity Hospital, Newcastle upon Tyne). 'Suggestions concerning the nomenclature of birthweight and gestational age.'

\section{Demonstrations}

D. Bell. 'Fetal heart monitoring before labour and in the light-for-dates baby.'

T. Lind. 'Biochemical and cytological studies of amniotic fluid as an aid to the assessment of gestational age.'

J. M. Parkin. 'Practical application of external characteristics of the newborn baby in the assessment of gestation age.'

M. J. Landon and F. E. Hytten. 'Folate transfer to the fetus.'

R. J. Scothorne and J. E. Bell. 'Electron microscopic study of secretory activity in the fetal sheep parathyroid.'

R. J. Scothorne and R. W. Graham. 'Calcium homeostasis in the guinea-pig fetus.'

J. M. McLean. 'The uterus as an immunologically privileged site.'

A. D. Hally. 'The control of the growth of the salt gland in the domestic duck.' 